\title{
Effects of grazing and fertilization on epiphyte growth dynamics under moderately eutrophic conditions: implications for grazing rate estimates
}

\author{
Just Cebrian $^{1,2, *}$, Jason P. Stutes ${ }^{1,2,3}$, B. Christiaen ${ }^{1,2}$ \\ ${ }^{1}$ Dauphin Island Sea Lab, 101 Bienville Blvd, Dauphin Island, Alabama 36528, USA \\ ${ }^{2}$ Department of Marine Sciences, University of South Alabama, LSCB 25, Mobile, Alabama 36688-0002, USA \\ ${ }^{3}$ Present address: Pentec Environmental/Hart Crowser, Inc., 120 Third Ave S, Edmonds, Washington 98020, USA
}

\begin{abstract}
The effects of grazing and nutrients on epiphyte biomass in seagrass beds have received much attention, yet less is known about effects on other metrics of epiphyte growth dynamics, such as epiphyte productivity and biomass turnover rates. To help address this gap, we present here a number of mesocosm experiments in which we manipulate grazer presence and nutrient concentrations under initially moderate eutrophic conditions. We also examine the potential bias contained in estimates of epiphyte grazing that disregard the effects of grazing on epiphyte productivity. The effects of grazing and nutrient enrichment on the epiphyte growth metrics examined were disparate. Namely, the effects of grazing on epiphyte biomass predominated over those of nutrient enrichment, but grazing and nutrients had similar importance as controls of epiphyte productivity and biomass turnover rates. The results illustrate that the effects of environmental and biological factors on one given metric of epiphyte growth dynamics can be quite different from those on other metrics. Thus, we suggest that the biomass-centered view mostly used to date in studies of epiphyte dynamics should perhaps shift toward a broader approach including other metrics of epiphyte growth, such as productivity and turnover rates, to better understand epiphyte dynamics in coastal systems and cascading functional consequences in the system. Another risk of biomass-centered studies lies in the calculation of grazing rates since, as also shown here, estimates of grazing rates derived as the difference in biomass accrual rates between non-grazed and grazed conditions can be highly biased.
\end{abstract}

KEY WORDS: Seagrass $\cdot$ Epiphyte $\cdot$ Halodule wrightii $\cdot$ Eutrophication $\cdot$ Grazing Resale or republication not permitted without written consent of the publisher

\section{INTRODUCTION}

Seagrass fauna represent a unique and diverse assemblage of organisms that directly or indirectly rely on the meadow as a source of energy and/or shelter (Virnstein et al. 1983, Heck et al. 2003). The seagrass itself, sediment microalgae, epiphytic algae, loose macroalgal mats and phytoplankton constitute the trophic base of food webs in seagrass beds (Cebrian 2004, Hauxwell \& Valiela 2004). Understanding the complex set of trophic interactions between seagrass fauna and their prey has presented a challenge (Hemminga \& Duarte 2000, Duffy et al. 2003, Mateo et al. 2006, Douglass et al. 2010). Anthropogenic eutrophication often stimulates epiphytic and macroalgal growth, further complicating these interactions (Sand-Jensen \& Borum 1991, Duarte 1995, Borum \& Sand-Jensen 1996). In some instances, the algae accumulate in quantities large enough to cause substantial shading and hypoxic/ anoxic conditions and subsequent seagrass mortality (Sfriso \& Marcomini 1997, Hauxwell et al. 2001, 2003, 
Orth et al. 2006), but in other instances, grazers can control nutrient-induced algal growth and dampen the deleterious effects on the seagrass (Heck et al. 2000, 2006, Hughes et al. 2004).

Epiphytic algae can be highly productive and account for up to $60 \%$ of the total primary productivity in seagrass beds (Morgan \& Kitting 1984, Silberstein et al. 1986, Moncreiff et al. 1992). Epiphyte grazers include species of crustaceans, gastropods, polychaetes, sea urchins and small fish (Luczkovich et al. 1995, Jernakoff et al. 1996, Hillebrand et al. 2000, Tomas et al. 2005). Epiphyte grazers are the preferred prey for many consumers, thus representing a trophic cornerstone for food webs in seagrass beds (Orth \& Van Montfrans 1984, Van Montfrans et al. 1984, Jernakoff \& Nielsen 1997, Moore \& Wetzel 2000). They also constitute important intermediaries in the cycling of carbon and nutrients in seagrass beds (Klumpp et al. 1992, 1993, Jernakoff et al. 1996).

In the present study, we focus on the interactions between grazers and epiphytic algae and the resulting effects on the seagrass host. Here, we add to a series of studies that have focused on the effects on epiphyte biomass accrual (e.g. Williams \& Ruckelshaus 1993, Neckles et al. 1993, 1994, Heck et al. 2006, Baggett et al. 2010) by examining how varying grazing and nutrient enrichment affects the productivity of epiphytes, both on an epiphyte weight-specific basis and on a leaf weight-specific basis, as well as the net accumulation of epiphyte biomass on seagrass leaf blades and the resulting effects on seagrass growth. This adds to our understanding of how different conditions of nutrient availability and grazing intensity may affect primary productivity and biomass, trophic support of secondary and higherlevel consumers and the cycling of carbon and nutrients in seagrass beds.

We pursued a second goal with the present study: the critical evaluation of conventional estimates of epiphyte grazing based on differences in epiphyte biomass accrual between grazed and non-grazed treatments. Epiphyte grazing has been addressed experimentally through a variety of techniques, such as analyses of gut contents, fecal pellets, radionuclide labeling and stable isotope signatures, but the most prevalent method is the use of enclosure/ exclosure experimental designs (Klumpp et al. 1992, Neckles et al. 1993, Jernakoff \& Nielsen 1997, Bostrom \& Mattila 1999, Duffy \& Hay 2000, Heck et al. 2000). The difference in epiphyte biomass accrual between non-grazed and grazed treatments observed in enclosure/exclosure experiments may be regarded as an estimate of epiphyte grazing (for a review, see Cebrian 2004). The rationale for this is as follows. Under grazed conditions, the rate of epiphyte biomass accrual corresponds to:

$$
\begin{aligned}
& (\text { Epiphyte biomass accrual })_{\text {GRAZED }}= \\
& (\text { Epiphyte productivity) })_{\text {GRAZED }}- \\
& (\text { Grazing })_{\text {GRAZED }}-(\text { Other losses })_{\text {GRAZED }}
\end{aligned}
$$

where (Epiphyte productivity) $)_{\text {GRAZED }}$ denotes the rate of epiphyte productivity, (Grazing) GRAZED $_{\text {is the rate }}$ of biomass loss to consumption by grazers, and (Other losses) GRAZED is the rate of other (i.e. non-consumptive) biomass losses, such as sloughing, under the presence of grazers. Following the same logic, the rate of epiphyte biomass accrual in the absence of grazers (non-grazed conditions) corresponds to:

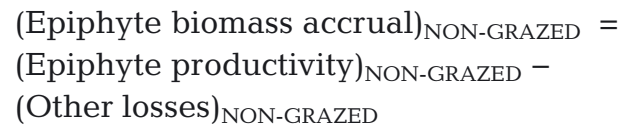

Rearranging Eqs. (1) \& (2), we can derive grazing rates as follows:

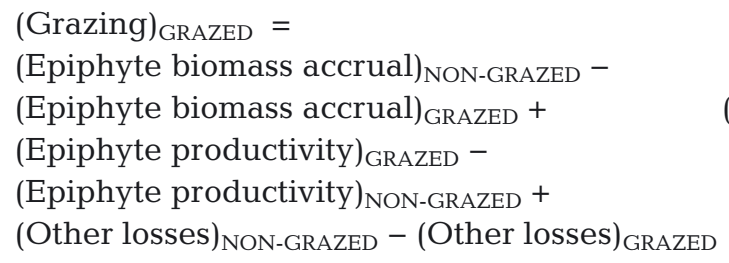

Thus, estimates of epiphyte grazing rates simply derived as the difference in epiphyte biomass accrual rates between non-grazed and grazed conditions may be substantially biased depending on how much the rates of epiphyte productivity and non-consumptive losses of epiphyte biomass differ between nongrazed and grazed conditions. Namely, it is clear that if grazers have a strong influence on rates of epiphyte productivity and/or non-consumptive losses (i.e. either one or both of them simultaneously) through direct or indirect mechanisms, then estimates of grazing rates that are simply calculated as the difference in epiphyte biomass accrual rates between nongrazed and grazed conditions may be largely equivocal. Here, we run a series of experiments to set quantitative limits to the potential extent of such bias.

\section{MATERIALS AND METHODS}

\section{Experimental setup}

We collected shoalgrass Halodule wrightii, epiphytes and grazers from a bed located at Pointe Aux Pins, $26 \mathrm{~km}$ northwest from the Dauphin Island Sea 
Lab (Alabama, USA). Epiphyte and grazer abundance vary seasonally at this site, offering several grazer/epiphyte combinations for comparison (Stutes 2000, Anton et al. 2009). To investigate grazer and nutrient effects on epiphyte biomass and productivity, a radio-labeling $\left({ }^{14} \mathrm{C}\right.$ ) technique (Wetzel 1964, Morgan \& Kitting 1984, Moncreiff et al. 1992) was employed in conjunction with a mesocosm study. Three experiments were performed seasonally during 2004 (Table 1), representing a range of environmental conditions and interactions among nutrient availability, grazers, epiphytes and the host seagrass. The experiments were performed in twelve $19 \mathrm{l}$ glass aquaria placed in an outdoor mesocosm facility at the Dauphin Island Sea Lab. The experiments examined grazing effects (no grazers or in situ grazer density), nutrient effects (ambient or increased nutrients) and their interaction, with a total of 4 treatments and 3 replicates per treatment in each experiment.

The sediment used in the aquaria was collected from the study site and defaunated (i.e. the infauna was killed by storing the sediment outdoors for $1 \mathrm{wk}$ prior to starting the experiment) to prevent side effects of infaunal patchiness (i.e. bioturbation) and help control for the grazer abundances seeded in the aquaria. Upon defaunation, sediment was placed and leveled in each of the aquaria to a height $\sim 5 \mathrm{~cm}$ from the bottom.

The aquaria were subsequently filled to $\sim 5.0 \mathrm{~cm}$ beneath the top edge with $20 \mu \mathrm{m}$-filtered bay seawater that had been collected near $(<100 \mathrm{~m})$ the mesocosm facility. The water used to fill up the aquaria was moderately eutrophic, similar to the water at the seagrass bed from which the samples were obtained. Work carried out in 2005 (Table 2; for more details, see Cebrian et al. 2008, Anton et al. 2009, 2011, Plutchak et al. 2010) showed substantial overlap in seawater concentrations of dissolved inorganic nitrogen (DIN) and phosphate (DIP) between the seagrass bed and the site where the mesocosm water was collected, although mean values were slightly higher at the mesocosm water collection site.

The aquaria were placed outdoors in a bath with running ambient, unfiltered bay seawater that flowed around the aquaria (surrounding the aquaria completely and approximately extending up to twothirds of the aquarium height) to achieve ambient water temperature and diel light cycles (Duffy \& Hay 2000, Pilon et al. 2003). The water within the aquaria was aerated with air stones throughout the experiment to maintain adequate oxygen levels and water circulation. Typical levels of light attenuation as observed at the study site were simulated with shade cloth placed over the aquaria (Table 1). The sediment was allowed to settle for $1 \mathrm{~d}$ after the aquaria had been filled up with water.

Shoots of Halodule wrightii were collected by hand from different locations across the bed and pooled in a large container. Care was taken to preserve epiphytes and rhizomes in the samples collected. Grazers (in this case, a composite of amphipod species from the genera Gammarus, Ampithoe, Ampelisca

Table 1. Specific dates, light irradiance $\left(\mu \mathrm{mol} \mathrm{m} \mathrm{m}^{-2} \mathrm{~s}^{-1}\right.$ just above the water surface, mean $\left.\pm \mathrm{SE}\right)$, transmittance (\% of irradiance reaching the top of the seagrass canopy, mean $\pm \mathrm{SE}$ ), mean densities of seagrass shoots, amphipods and gastropods (in number per aquarium or number per square meter in parentheses), and the ratio of grazer (sum of amphipods and gastropods) to shoot density in the 3 experiments done in 2004

\begin{tabular}{|lccccccc|}
\hline & $\begin{array}{c}\text { Specific } \\
\text { dates }(\mathrm{mm} / \mathrm{dd})\end{array}$ & Irradiance & Transmittance & $\begin{array}{c}\text { Seagrass } \\
\text { shoot density }\end{array}$ & $\begin{array}{c}\text { Amphipod } \\
\text { density }\end{array}$ & $\begin{array}{c}\text { Gastropod } \\
\text { density }\end{array}$ & $\begin{array}{c}\text { Ratio of grazers } \\
\text { to shoot density }\end{array}$ \\
\hline Spring & $5 / 7-5 / 14$ & $2642.7 \pm 30.2$ & $42.7 \pm 1.2$ & $290(2900)$ & $330(3300)$ & $21(210)$ & 1.2 \\
Summer & $8 / 13-8 / 20$ & $2378.0 \pm 46.1$ & $57.3 \pm 1.9$ & $110(1100)$ & $20(200)$ & $9(90)$ & 0.26 \\
Fall & $11 / 12-11 / 19$ & $2078.3 \pm 25.8$ & $49.3 \pm 0.9$ & $53(530)$ & $6(60)$ & $2(20)$ & 0.15 \\
\hline
\end{tabular}

Table 2. Environmental conditions at the seagrass bed and the bay site where the water used for the mesocosms was collected. Values were obtained from a series of unrelated experiments conducted at the same locations in 2005. See 'Experimental setup' for details. DIN: dissolved inorganic nitrogen; DIP: dissolved inorganic phosphate

\begin{tabular}{|c|c|c|c|c|c|c|c|c|}
\hline & \multicolumn{2}{|c|}{ — Temperature $\left({ }^{\circ} \mathrm{C}\right)-$} & \multicolumn{2}{|c|}{- Salinity (ppt) } & \multicolumn{2}{|c|}{- DIN $(\mu \mathrm{M})-$} & \multicolumn{2}{|c|}{- DIP $(\mu \mathrm{M})-$} \\
\hline & Range & Mean \pm SE & Range & Mean \pm SE & Range & Mean $\pm \mathrm{SE}$ & Range & Mean \pm SE \\
\hline Seagrass bed & $12.3-31.3$ & $25.9 \pm 0.9$ & $21.3-30.3$ & $27.3 \pm 0.5$ & $0.10-4.92$ & $1.1 \pm 0.2$ & $0.06-0.52$ & $0.14 \pm 0.01$ \\
\hline $\begin{array}{l}\text { Bay seawater } \\
\text { collection site }\end{array}$ & $14.2-33.7$ & $24.9 \pm 0.8$ & $7.4-29.4$ & $16.5 \pm 0.7$ & $0.03-16.46$ & $4.5 \pm 0.2$ & $0.05-0.92$ & $0.26 \pm 0.01$ \\
\hline
\end{tabular}


and Corophium and 1 gastropod species, Neritina usnea) were collected using air conditioner filters. The filters offer a highly complex habitat that attracts amphipods, gastropods and other small crustaceans. This method has been proven successful for collecting mesograzers in seagrass beds with relatively little effort and practically no disturbance to the seagrass bed, in contrast to coring, which would involve substantial removal of seagrass biomass in order to collect similar mesograzer quantities as collected with the air filters (Heck et al. 2000, Spitzer et al. 2003). Upon collection, the filters were rinsed and sieved through a $500 \mu \mathrm{m}$ mesh, and the amphipods and gastropods retained on the sieve were then separated.

Shoots were collected on the day after the sediment in the aquaria settled and were planted the same day. Three samples consisting of 5 shoots per sample were randomly taken from the pooled seagrass shoots to determine the epiphyte load at the beginning of the experiment. Air conditioner filters were deployed in the field for 4 to $6 \mathrm{~d}$ prior to starting the experiment. Grazers were collected $1 \mathrm{~d}$ after planting the shoots and stocked in the aquaria that same day ( $<3 \mathrm{~h}$ elapsed between collection and stocking). Shoots and grazers were both stocked at in situ densities, which were determined a few days before starting the experiment by haphazardly taking five $15.5 \mathrm{~cm}$ inner-diameter PVC cores in the bed (Table 1).

We measured the concentration of DIN and DIP in the filtered water used to fill up the aquaria. These concentrations were measured with a Skalar SAN ${ }^{+}$ autoanalyzer following standard procedures (Strickland \& Parsons 1972, Pennock \& Cowan 2001). Based on those measurements, we then calculated the quantity of nutrient solution to be added to each fertilized aquarium in order to increase the ambient concentrations of DIN and DIP 3-fold. This corresponds to a moderate level of increase in relation to the levels applied in other fertilization experiments (Downing et al. 1999, Worm et al. 2000). Nutrients were added shortly after the grazers. Measurements taken $1 \mathrm{~h}$ after adding the nutrients revealed that immediate increases in nutrient concentration were variable (Table 3), ranging on average from 2- to 9-fold among experiments for DIN and from 2- to 5fold for DIP. Discrepancies between targeted and realized increases in nutrient concentration often occur in fertilization experiments due to factors that are not well known and/or cannot be controlled with accuracy (Worm et al. 2000, Stutes et al. 2006, Cebrian et al. 2009). Here, it is possible that nutrient efflux from the settling sediment into the overlying water within the aquaria may have contributed to the higher level of enrichment found in some of the experiments (Sundbäck et al. 1991, Rizzo et al. 1992, Hardison et al. 2010). In spite of this, the level of increase in nutrient concentration attained with our initial additions still remains moderate in relation to other fertilization experiments (Downing et al. 1999, Worm et al. 2000).

Prior similar experiments (Stutes 2000) showed that seagrass and attached epiphytes can absorb substantial amounts of water-column nutrients in closed aquaria (i.e. no flow through) over the course of $1 \mathrm{wk}$ (which corresponds to the duration of our experiments). Thus, to prevent nutrient limitation in the control aquaria and maintain elevated nutrient concentrations in the fertilized in relation to control aquaria throughout the duration of the present study, we spiked additional nutrients midway during the experiment (Day 3) in all aquaria (both control and fertilized). These additional quantities were calculated from the temporal dynamics of nutrient concentration in non-fertilized and fertilized closed aquaria containing seagrass and epiphytes that were observed in the prior experiments mentioned above (Stutes 2000). In the present study, we did not measure nutrient concentrations shortly after spiking the additional quantities or at the end of the experiments. However, based on our previous work (Stutes 2000), our initial and mid-way nutrient addition should prevent nutrient limitation in the control aquaria and maintained elevated nutrient levels in the fertilized in relation to non-fertilized aquaria throughout the duration of the experiments, with these differences corresponding to moderate levels of enrichment in comparison with other studies. Also, these extra quantities added midway through the experiment should not enrich the control aquaria in relation 
to ambient conditions but rather prevented nutrient limitation. Salinity in the aquaria was monitored daily and maintained within 0.5 ppt of initial conditions using deionized water to make up for evaporative losses.

The aquaria were incubated for $7 \mathrm{~d}$. At the end of this period, 16 shoots and attached epiphytes were randomly sampled from each aquarium. Ten of the 16 shoots were frozen for determination of epiphyte biomass, and the other 6 shoots were used for the radio-labeling $\left({ }^{14} \mathrm{C}\right)$ assay. Although we did not separate and count grazers in the aquaria at the end of the experiments, careful visual inspection at that time revealed that non-grazed aquaria contained virtually no grazers and that most of the grazers initially placed in grazed aquaria were alive and active.

\section{Response variables}

We used the ${ }^{14} \mathrm{C}$ incubation method to measure the productivity of the epiphytes and the host seagrass. The method was first introduced by Steemann Nielsen (1951) for phytoplankton and has since been adapted for aquatic macrophytes and attached epiphytes (Wetzel 1964, Capone et al. 1979, Morgan \& Kitting 1984, Moncreiff et al. 1992). The method relies on measuring carbon uptake by the primary producers using the radioactive marker ${ }^{14} \mathrm{C}$. When corrected for inactive (e.g. adsorption of inorganic carbon to particles) and chemotrophic carbon uptake (e.g. marine nitrifiers), it provides a direct measurement of the inorganic carbon actively taken up by primary producers for their growth (i.e. a direct measurement of primary productivity). Such correction is best achieved using the compound dichlorophenyl dimethyl urea (DCMU), which specifically inhibits active uptake by primary producers (Legendre et al. 1983, Markager 1998). Thus, the difference in carbon uptake between DCMU-free and DCMU-spiked clear incubations corresponds to the amount of carbon actively taken by primary producers. DMCU is regarded as a better corrective choice than dark incubations because some primary producer metabolical processes that lead to active carbon uptake, such as the Wood-Werkman pathway, only occur in dark conditions (Legendre et al. 1983). Controversy regarding the use of the ${ }^{14} \mathrm{C}$ method arises when different versions of the method (e.g. using dark bottles to correct for inactive and chemotrophic carbon uptake), or when this and other methods to measure primary productivity (e.g. oxygen evolution), are combined in the same experi- ment, but if the same ${ }^{14} \mathrm{C}$ procedure based on DCMU blanks is used throughout the experiment, the method provides robust, well-validated measurements of primary productivity (Arthur \& Rigler 1967 , Peterson 1980, Kemp et al. 1986).

For the ${ }^{14} \mathrm{C}$ experiments, 3 shoots and attached epiphytes were placed in each of twelve $50 \mathrm{ml}$ centrifuge tubes (1 tube per aquarium) with $45.0 \mathrm{ml}$ of filtered aquarium seawater labeled with $4.0 \mu \mathrm{Ci}$ of $\mathrm{NaH}^{14} \mathrm{CO}_{3}$. Immediately after transfer, the tubes were inverted and placed back in their respective aquaria. A second set of twelve $50 \mathrm{ml}$ tubes containing 3 shoots each (also 1 tube for each aquarium) were spiked with DCMU to a final concentration of $10^{-5} \mathrm{M}$. Before placement, we made sure none of these chemicals leaked out of the tubes. The tubes were incubated for $3.0 \mathrm{~h}$ beginning at 09:00 $\mathrm{h}$ on Day 8 of the experiment. All incubations in all experiments started approximately at that time. In tropical and subtropical latitudes, such as our experimental sites, incubations for primary productivity during early to mid morning may help avoid elevated photorespiration at midday under intense sunlight (Ralph et al. 1998, Ralph 1999). The incubations were terminated by adding $4 \%$ formalin solution.

After incubation, the seagrass leaves with attached epiphytes were removed and washed with $\sim 25 \mathrm{ml}$ of $2.0 \% \mathrm{HCL}$ onto a pre-weighed $0.7 \mu \mathrm{m}$ pore size glass-fiber filter to remove unincorporated label and catch any loosely attached epiphytes. Seagrass and epiphytes were separated using a dulled razor blade on a glass plate. Separation of epiphytes from seagrass blades through scraping works well in cases where, as here, most epiphytes are soft-bodied (i.e. mostly consisting of filamentous algae and/or microalgae, such as diatoms and cyanobacteria, embedded in a mucilaginous periphyton matrix and with little to no occurrence of calcareous encrusting algae; Dauby \& Poulicek 1995, Antón et al. 2011). The epiphytes were added to the filter, and the seagrass leaves were placed in a pre-weighed drying tin. Both were dried at $80^{\circ} \mathrm{C}$, re-weighed and then placed into separate $15 \mathrm{ml}$ Pyrex ${ }^{\mathrm{TM}}$ digestion vials. The samples were then digested with $10.0 \mathrm{ml}$ of concentrated nitric acid for a minimum of $24 \mathrm{~h}$. After digestion, the vials were centrifuged, and $0.5 \mathrm{ml}$ of supernatant was added to $4.5 \mathrm{ml}$ of Tris buffer solution. Then, $0.5 \mathrm{ml}$ of that mixture was added to $4.5 \mathrm{ml}$ of scintillation cocktail (EcoLume). A Packard Tri-Carb 2500-TR scintillation counter was used to record the radioactivity of each sample as decays per minute (dpm), which was then standardized per unit of biomass dry weight (DW) for both regular samples and DCMU blanks. The DCMU 
blank was then subtracted out, and the reading was converted into units of weight-specific productivity (SP) or $\mathrm{mg} \mathrm{C} \mathrm{g}^{-1} \mathrm{DW} \mathrm{h}^{-1}$ for each producer type (i.e. epiphyte or seagrass) using the following equation:

$$
\mathrm{SP}=\left(D_{\mathrm{c}} \times V \times \mathrm{Alk} \times \mathrm{CT} \times \mathrm{DF}\right) /\left(t \times D_{\mathrm{a}}\right)
$$

where $D_{\mathrm{c}}$ is the DCMU-corrected sample activity in dpm $\left(\mathrm{g}^{-1} \mathrm{DW}\right), V$ is the volume incubated in the tube $(0.045 \mathrm{l})$, Alk is the alkalinity of the incubated

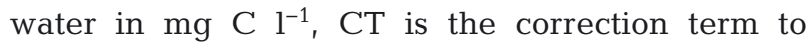
account for differential isotopic uptake (1.064), DF is the dilution factor (200), $t$ is the incubation time $(3 \mathrm{~h})$, and $D_{\mathrm{a}}$ is the absolute activity in the incubation tube $\left(8.88 \times 10^{6} \mathrm{dpm}\right)$. Alkalinity was measured in each aquarium at the time of incubation using a Shimadzu TOC-500 fitted with a non-dispersive IR detector. To calculate epiphyte absolute productivity (mg C g ${ }^{-1}$ seagrass DW $\mathrm{h}^{-1}$ ), both for regular samples and DCMU blanks, we divided the epiphyte dpm by the weight of the corresponding leaves from which the epiphytes had been collected, subtracted out the DCMU blank from the regular sample and applied Eq. (4).

To determine epiphyte biomass, the epiphyte material was removed from the leaf surface using a dulled razor blade, and epiphytes and seagrass leaves were placed into separate pre-weighed drying tins. Samples were dried at $80^{\circ} \mathrm{C}$, re-weighed, and the epiphyte biomass was standardized per unit of seagrass biomass (i.e. g DW epiphyte biomass per $g$ DW seagrass biomass). The 10 shoots from each aquarium were pooled (i.e. sum of total epiphyte biomass for the 10 shoots divided by the total weight of the 10 shoots) into 1 true replicate for statistical analysis.

\section{Statistical analysis}

For each of the response variables (final epiphyte biomass, weight-specific epiphyte and seagrass productivity and absolute epiphyte productivity), separate 2-way ANOVAs were run for each experiment (spring, summer and fall) with nutrients (control or increased concentrations) and grazing (no grazing or in situ grazing) as fixed factors. Data sets were tested for normality and heterocedasticity and natural logtransformed when necessary in order to meet the assumptions of ANOVA. Post-hoc comparisons were done with the Tukey's pairwise multiple comparison test. Differences were considered significant at $\alpha=$ 0.05 . The statistical analyses were done with Minitab 13.0 (SPSS).

\section{RESULTS}

\section{Epiphyte biomass}

We detected a significant main effect of grazing but not of nutrient enrichment in the spring and summer trials (Table 4). There was not a significant inter-

Table 4. Two-way ANOVA (G: grazing; N: nutrients) and Tukey tests (NG: non-grazed; G: grazed; NF: non-fertilized; F: fertilized)

\begin{tabular}{|c|c|c|c|}
\hline $\begin{array}{l}\text { Response variable } \\
\text { Experiment }\end{array}$ & \multicolumn{2}{|c|}{ 2-way ANOVA } & Tukey tests \\
\hline \multicolumn{4}{|l|}{ Epiphyte biomass } \\
\hline Spring & $\begin{array}{c}\mathrm{G} \\
\mathrm{N} \\
\mathrm{G} \times \mathrm{N}\end{array}$ & $\begin{array}{l}p<0.05 \\
p=0.59 \\
p=0.09\end{array}$ & $\mathrm{NG}>\mathrm{G}$ \\
\hline Summer & $\begin{array}{c}\mathrm{G} \\
\mathrm{N} \\
\mathrm{G} \times \mathrm{N}\end{array}$ & $\begin{array}{l}p<0.05 \\
p=0.44 \\
p=0.08\end{array}$ & $\mathrm{NG}>\mathrm{G}$ \\
\hline Fall & $\begin{array}{c}\mathrm{G} \\
\mathrm{N} \\
\mathrm{G} \times \mathrm{N}\end{array}$ & $\begin{array}{l}p<0.05 \\
p<0.05 \\
p<0.05\end{array}$ & $\begin{aligned} \text { NGNF } & >\text { GNF } \\
\text { NGF } & =\text { GF } \\
\text { NGNF } & =\text { NGF } \\
\text { GNF } & <\text { GF }\end{aligned}$ \\
\hline \multicolumn{4}{|c|}{ Epiphyte absolute productivity } \\
\hline Spring & $\begin{array}{c}\mathrm{G} \\
\mathrm{N} \\
\mathrm{G} \times \mathrm{N}\end{array}$ & $\begin{array}{l}p<0.05 \\
p=0.91 \\
p=0.92\end{array}$ & $\mathrm{NG}>\mathrm{G}$ \\
\hline Summer & $\begin{array}{c}\mathrm{G} \\
\mathrm{N} \\
\mathrm{G} \times \mathrm{N}\end{array}$ & $\begin{array}{l}p=0.06 \\
p<0.05 \\
p=0.07\end{array}$ & $\mathrm{NF}<\mathrm{F}$ \\
\hline Fall & $\begin{array}{c}\mathrm{G} \\
\mathrm{N} \\
\mathrm{G} \times \mathrm{N}\end{array}$ & $\begin{array}{l}p<0.05 \\
p<0.05 \\
p<0.05\end{array}$ & 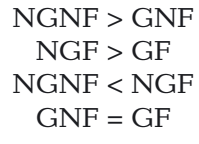 \\
\hline \multicolumn{4}{|c|}{ Epiphyte weight-specific productivity } \\
\hline Spring & $\begin{array}{c}\mathrm{G} \\
\mathrm{N} \\
\mathrm{G} \times \mathrm{N}\end{array}$ & $\begin{array}{l}p<0.05 \\
p=0.31 \\
p<0.05\end{array}$ & $\begin{aligned} \mathrm{NGNF} & <\mathrm{GNF} \\
\mathrm{NGF} & =\mathrm{GF} \\
\mathrm{NGNF} & =\mathrm{NGF} \\
\mathrm{GNF} & =\mathrm{GF}\end{aligned}$ \\
\hline Summer & $\begin{array}{c}\mathrm{G} \\
\mathrm{N} \\
\mathrm{G} \times \mathrm{N}\end{array}$ & $\begin{array}{l}p=0.68 \\
p<0.05 \\
p=0.07\end{array}$ & $\mathrm{NF}<\mathrm{F}$ \\
\hline Fall & $\begin{array}{c}\mathrm{G} \\
\mathrm{N} \\
\mathrm{G} \times \mathrm{N}\end{array}$ & $\begin{array}{c}p<0.05 \\
p=0.5 \\
p<0.05\end{array}$ & $\begin{aligned} \text { NGNF } & <\text { GNF } \\
\text { NGF } & =\text { GF } \\
\text { NGNF } & =\text { NGF } \\
\text { GNF } & =\text { GF }\end{aligned}$ \\
\hline \multicolumn{4}{|c|}{ Seagrass weight-specific productivity } \\
\hline Spring & $\begin{array}{c}\mathrm{G} \\
\mathrm{N} \\
\mathrm{G} \times \mathrm{N}\end{array}$ & $\begin{array}{l}p=0.91 \\
p<0.05 \\
p<0.05\end{array}$ & $\begin{aligned} \mathrm{NGNF} & =\mathrm{GNF} \\
\mathrm{NGF} & =\mathrm{GF} \\
\mathrm{NGNF} & =\mathrm{NGF} \\
\mathrm{GNF} & >\mathrm{GF}\end{aligned}$ \\
\hline Summer & $\begin{array}{c}\mathrm{G} \\
\mathrm{N} \\
\mathrm{G} \times \mathrm{N}\end{array}$ & $\begin{array}{l}p<0.05 \\
p=0.86 \\
p=0.44\end{array}$ & $\mathrm{NG}>\mathrm{G}$ \\
\hline Fall & $\begin{array}{c}\mathrm{G} \\
\mathrm{N} \\
\mathrm{G} \times \mathrm{N}\end{array}$ & $\begin{array}{l}p=0.70 \\
p=0.87 \\
p=0.70\end{array}$ & \\
\hline
\end{tabular}


action between grazing and nutrients in these trials. Indeed, grazer presence reduced biomass in comparison with non-grazed conditions to a similar extent, regardless of whether the aquaria had been enriched with nutrients or not (Fig. 1). However, in the fall trial, we detected a significant interaction between grazing and nutrients. Post-hoc analyses revealed that the presence of grazers reduced epiphyte biomass in relation to non-grazed conditions only under ambient nutrient conditions, but not under enriched nutrient conditions. Nutrient enrichment increased epiphyte biomass if grazers were present, but not when they were absent, in relation to ambient nutrient conditions (Fig. 1, Table 4).

\section{Epiphyte absolute productivity}

Grazer presence significantly decreased epiphyte absolute productivity in the spring trial. There was neither a significant main effect of nutrients nor a significant interaction between grazing and nutrients in this trial (Fig. 2, Table 4). In the summer trial, nutrient enrichment significantly increased epiphyte absolute productivity in relation to ambient nutrient conditions, and there was no significant main effect of grazing or interaction between the 2 factors. We found a significant interaction between grazing and nutrients in the fall trial. Post-hoc analyses showed that grazer presence reduced epiphyte absolute productivity in comparison with non-grazed conditions both under ambient and enriched nutrient conditions, but nutrient enrichment increased epiphyte absolute productivity in relation to ambient nutrient conditions only when grazers were absent, not when they were present (Fig. 2, Table 4).

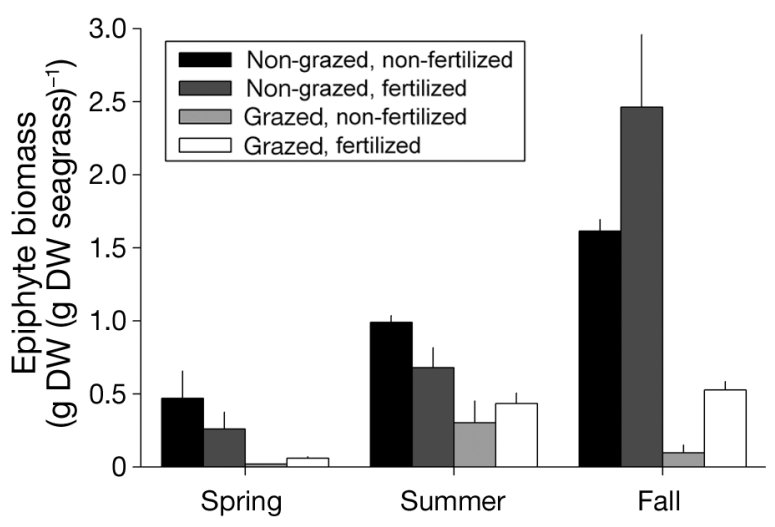

Fig. 1. Epiphyte biomass ( $\mathrm{g} \mathrm{DW} \mathrm{g}^{-1} \mathrm{DW}$ seagrass) in the spring, summer and fall experiments. Bars are means $\pm \mathrm{SE}$

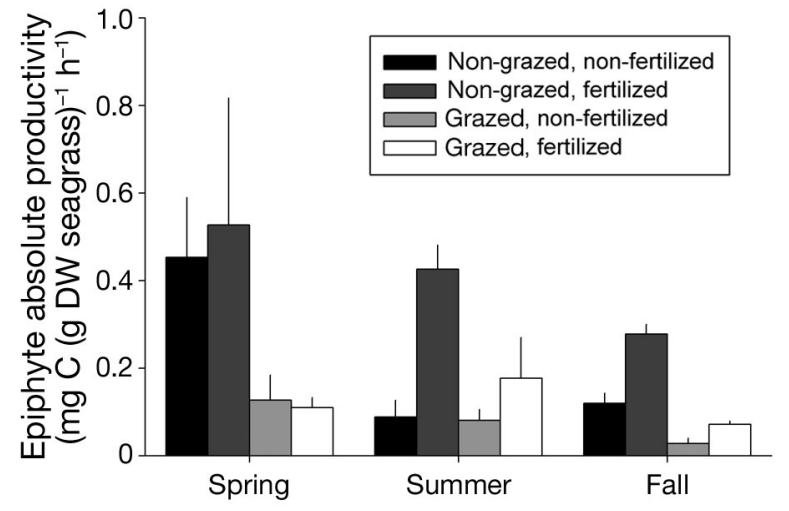

Fig. 2. Epiphyte absolute productivity $\left(\mathrm{mg} \mathrm{C} \mathrm{g}^{-1} \mathrm{DW}\right.$ seagrass $\mathrm{h}^{-1}$ ) in the spring, summer and fall experiments. Bars are means $\pm \mathrm{SE}$

\section{Epiphyte weight-specific productivity}

We found a significant interaction of grazing and nutrients on epiphyte weight-specific productivity in the spring trial. Post-hoc tests indicated that grazer presence increased epiphyte weight-specific productivity in comparison with non-grazed conditions under ambient nutrient conditions but not under enriched nutrient conditions. Nutrient enrichment did not increase or decrease epiphyte weight-specific productivity in relation to ambient nutrient conditions, regardless of whether grazers were present or absent (Fig. 3, Table 4). In the summer trial, nutrient enrichment significantly increased epiphyte weightspecific productivity in relation to ambient nutrient conditions, but there was no significant main effect of grazing or interaction between the 2 factors. The results for the fall trial were analogous to the results for the spring trial (Fig. 3, Table 4).

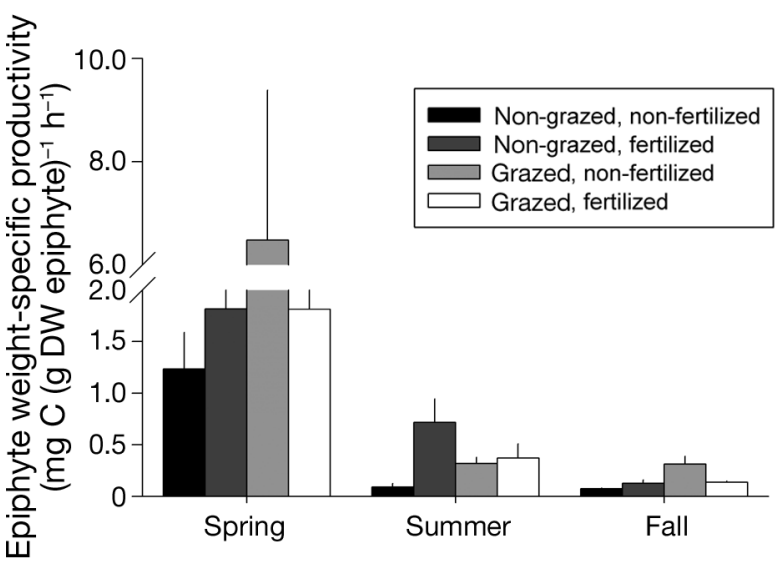

Fig. 3. Epiphyte weight-specific productivity $\left(\mathrm{mg} \mathrm{C}^{-1} \mathrm{DW}\right.$ seagrass $\mathrm{h}^{-1}$ ) in the spring, summer and fall experiments. Bars are means $\pm \mathrm{SE}$ 


\section{Seagrass weight-specific productivity}

In the spring trial, we found a significant interaction between grazing and nutrients on seagrass weight-specific productivity. Nutrient enrichment decreased seagrass-specific productivity in relation to ambient nutrient conditions when grazers were present, but not when they were absent. Grazing did not increase or decrease seagrass weight-specific productivity in relation to non-grazed conditions, regardless of whether the aquaria had been enriched with nutrients or not (Fig. 4, Table 4). In the summer trial, grazing significantly decreased seagrass weight-specific productivity in relation to non-grazed conditions. There was no significant main effect of nutrient enrichment or significant interaction between the 2 factors in this trial. We

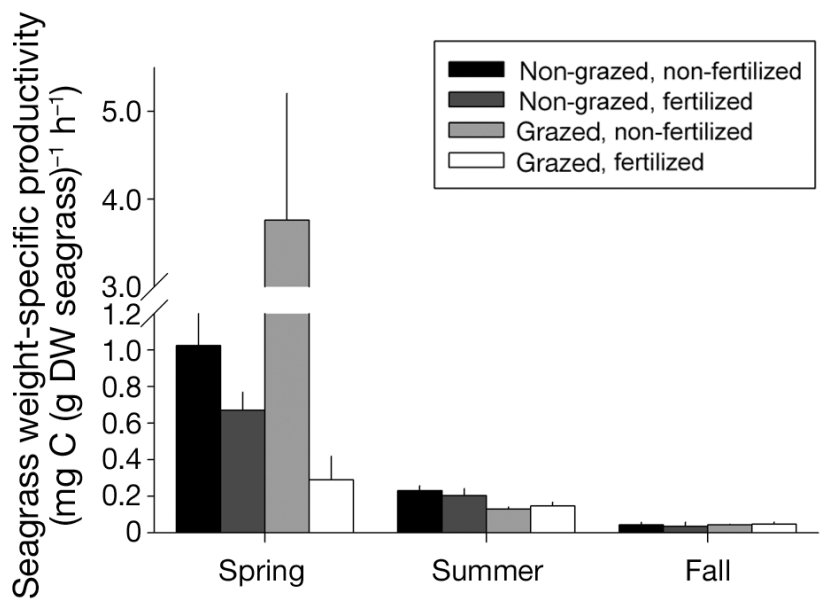

Fig. 4. Seagrass weight-specific productivity $\left(\mathrm{mg} \mathrm{C} \mathrm{g}^{-1} \mathrm{DW}\right.$ seagrass $\mathrm{h}^{-1}$ ) in the spring, summer and fall experiments. Bars are means $\pm \mathrm{SE}$ found no significant main grazing and nutrient effects or interactions between the 2 factors in the fall trial (Fig. 4, Table 4).

\section{Derivation of epiphyte grazing rates}

Eq. (3) illustrates how epiphyte grazing rates can be derived from grazer-exclosure experiments, such as the ones performed here. However, rates of absolute epiphyte productivity and non-consumptive losses of epiphyte biomass (e.g. sloughing) are rarely measured along with changes in epiphyte biomass in grazer-exclosure experiments. Thus, epiphyte grazing rates in most grazer-exclosure experiments can only be estimated from the difference in the rates of epiphyte biomass accrual between non-grazed and grazed conditions. Here, we have not made any attempt to measure rates of non-consumptive losses of epiphyte biomass, but our measurements allow us to set qualitative bounds to the extent of the potential bias in estimates of epiphyte grazing rates derived solely as the difference in the rates of epiphyte biomass accrual between non-grazed and grazed conditions. The results are summarized in Table 5. Namely, estimates of epiphyte grazing rates that include the effect of grazers on the rates of epiphyte absolute productivity found in our experiments could be $\sim 2$ to $30 \%$ lower than estimates derived solely as the difference in epiphyte biomass accrual rates between non-grazed and grazed conditions, assuming that the rates of non-consumptive losses under non-grazed and grazed conditions cancel each other out. These differences would be larger if rates of nonconsumptive losses are higher in grazed than in nongrazed treatments.

Table 5. Estimates of epiphyte grazing rates derived without and with consideration of effects on productivity and nonconsumptive losses. All estimates are expressed as g DW epiphytes $\mathrm{g}^{-1} \mathrm{DW}$ seagrass $\mathrm{d}^{-1}$. Estimates without consideration of effects on productivity and non-consumptive losses were simply derived as the difference in epiphyte biomass accrual between non-grazed and grazed treatments divided by the duration of the experiment $(7 \mathrm{~d})$, i.e. [(final epiphyte biomass - initial epiphyte biomass)non-grazed - (final epiphyte biomass - initial epiphyte biomass)grazed] / 7. Estimates which take those effects into consideration were derived using Eq. (3). Rates of absolute epiphyte productivity for non-grazed and grazed conditions (Epiphyte productivity ${ }_{\text {NON-GRAZED }}$ and Epiphyte productivity GRAZED $_{\text {) }}$ were derived from the measurements done on the last day of the experiments and expressed as g DW epiphytes $\mathrm{g}^{-1} \mathrm{DW}$ seagrass $\mathrm{d}^{-1}$ using C to DW conversion factors obtained from the literature (Cebrian 2004) and the length of daylight (number of light hours per day) on the incubation day. For sim-plification, values for non-fertilized and fertilized aquaria were pooled

\begin{tabular}{|c|c|c|}
\hline & $\begin{array}{l}\text { Without consideration of effects on } \\
\text { productivity and non-consumptive losses }\end{array}$ & $\begin{array}{l}\text { With consideration of effects on productivity } \\
\text { and non-consumptive losses }\end{array}$ \\
\hline Spring & 0.043 & $0.043-0.013+(\text { Other losses })_{\text {NON-GRAZED }}-(\text { Other losses })_{\text {GRAZED }}$ \\
\hline Summer & 0.086 & $0.086-0.007+(\text { Other losses })_{\text {NON-GRAZED }}-(\text { Other losses })_{\text {GRAZED }}$ \\
\hline Fall & 0.243 & $0.243-0.004+(\text { Other losses })_{\text {NON-GRAZED }}-(\text { Other losses })_{\text {GRAZED }}$ \\
\hline
\end{tabular}




\section{DISCUSSION}

Our results suggest that the effects of grazing and nutrient enrichment on diverse metrics of epiphyte growth (i.e. biomass, absolute productivity or productivity per leaf weight unit of the seagrass host, and weight-specific productivity or productivity per epiphyte weight unit) can be disparate. Grazing had a preponderant effect on biomass in comparison with the effect of nutrient enrichment. In 2 of the 3 trials, grazer presence caused large reductions in epiphyte biomass, and nutrient enrichment did not have any significant effects. In the third trial, we found an interaction between the 2 factors, but the reduction in epiphyte biomass due to grazing under ambient nutrient conditions was larger in magnitude (as indicated by the respective $F$-values) than the increase in epiphyte biomass that occurred following nutrient enrichment when grazers were present. Interestingly, we did not find a clear predominance of grazing effects over nutrient effects on the other 2 metrics of epiphyte growth examined, i.e. absolute epiphyte productivity and weight-specific epiphyte productivity. Regarding absolute epiphyte productivity, one trial showed significant decreases due to grazing but no effect of nutrients, another trial showed significant increases due to nutrients but no effect of grazing, and the third trial showed a complex interaction with significant reductions due to grazing, regardless of nutrient condition, and a significant increase due to nutrients only when grazers were absent. For weight-specific productivity, 2 of the trials showed significant increases due to grazing under ambient but not under enriched nutrient conditions, and no increases or decreases due to nutrient enrichment with grazers present or absent, whereas the other trial showed significant increases due to nutrients but no effect of grazing.

In concert, these results illustrate that the effects of grazing and nutrients on a given measure of epiphyte growth do not necessarily cascade equivalently onto other growth measures. For instance, nutrient enrichment had little impact overall on epiphyte biomass. Out of the 3 trials, we only found 1 instance of significant effects of nutrient enrichment on epiphyte biomass, whereby nutrient enrichment increased biomass when grazers were present in the fall trial. Interestingly, nutrient enrichment never increased epiphyte biomass when grazers were absent, which contrasts with results from previous experiments (Neckles et al. 1993, 1994, Williams \& Ruckelshaus 1993, Peterson et al. 2007). The lack of a major consistent impact of nutrient enrichment on epiphyte biomass in our trials could be due to the background eutrophic conditions in our mesocosms and in the seagrass beds where the samples were collected (Cebrian et al. 2008, Anton et al. 2009, Plutchak et al. 2010). Consistent with these naturally eutrophic levels, the levels of epiphyte biomass in the samples incubated in the mesocosms were high in comparison with values reported in the literature (Borum 1987, Neckles et al. 1993, Cebrian et al. 1999, Hauxwell et al. 2001, 2003, Stutes et al. 2007, Jaschinski \& Sommer 2010), even when those levels were reduced under the presence of grazers. High levels of epiphyte biomass may imply thick and dense canopies, which through intense self-shading and limited nutrient and gas diffusion may dampen a positive response of epiphyte biomass to nutrient enrichment (Sand-Jensen \& Borum 1984, 1991, Van Montfrans et al. 1984, Duarte 1995). The only instance of positive biomass response to nutrient enrichment found under the presence of grazers suggests that grazers may somewhat alleviate the restraining effects of thick epiphyte canopies and allow for significant increases of epiphyte biomass. These results are qualitatively similar to previous experiments that have shown little effect of nutrient enrichment on periphyton biomass under eutrophic conditions (Hillebrand \& Kahlert 2002, Cebrian et al. 2009, 2012).

However, in clear opposition to the lack of major, consistent effects of nutrient enrichment on epiphyte biomass, nutrient enrichment did significantly increase epiphyte productivity per gram of seagrass leaf (epiphyte absolute productivity) in the summer trial and in the fall trial when grazers were not present, but this did not translate into parallel changes in biomass. This indicates that the increased carbon uptake that occurred under nutrient enrichment during those trials did not result in significant increases in the production of new epiphytic biomass (i.e. larger biomass accrual). Perhaps the increased amount of carbon taken up by photosynthesis under nutrientenriched conditions during those trials, rather than resulting in the formation of new biomass, was mostly used for the metabolical support of bottom parts of thick epiphyte canopies subject to intense self-shading and limited diffusion (Agustí et al. 1994, Duarte 1995, Enríquez et al. 1996, Enríquez 2005). The effects of grazing and nutrients on epiphyte productivity per gram of epiphyte (epiphyte weightspecific productivity) appeared to be a combination of propagated effects on biomass and absolute productivity. In the spring and fall trials, the lowest values of biomass due to grazing under non-enriched 
conditions appeared to drive the significantly higher values of epiphyte weight-specific productivity found in those trials, and in the summer trial, the increase in absolute productivity observed with nutrient enrichment seemed to drive a parallel increase in epiphyte weight-specific productivity.

Therefore, caution should be exerted when inferring implications on epiphyte growth dynamics and cascade effects on the system from studies that only consider one of the growth metrics. For instance, here we find a preponderant effect of grazing on epiphyte biomass, which is in agreement with the large control of epiphyte biomass by grazers found in other studies (Neckles et al. 1993, Heck et al. 2000, 2006, Hughes et al. 2004, Gruner et al. 2008). However, these results do not necessarily provide much information about the effects of grazing and other environmental controls (e.g. nutrients) on other metrics of epiphyte growth (e.g. epiphyte productivity on a per leaf or per epiphyte weight basis), and as such, the implications and inferences of biomass-based results on the dynamics of epiphyte populations, and feedbacks on elemental cycling and trophic transfer in the system, are limited if other metrics of epiphyte growth are not considered. Epiphyte biomass is indicative of the quantity of carbon stored by epiphytes. Epiphyte absolute productivity (productivity on a per leaf weight basis) is indicative of the amount of carbon taken up by epiphytes through photosynthesis per unit of host biomass, and epiphyte weightspecific productivity (productivity on a per epiphyte weight basis) reflects carbon turnover through the epiphyte pool. On this basis, we show that in our experiments, grazing is a predominant factor over nutrient enrichment in the control of carbon storage as epiphyte biomass, but grazing and nutrient enrichment are more similar in terms of their overall importance in the control of photosynthetic carbon uptake by epiphytes and rates of carbon cycling through the epiphyte pool.

In the present study, we did not find cascading positive effects on seagrass weight-specific productivity from the large reductions in epiphyte biomass caused by grazing, unlike the results of other studies (Orth \& Van Montfrans 1984, Van Montfrans et al. 1984, Jernakoff et al. 1996). Perhaps the reduction of epiphyte biomass under grazed conditions observed here was in general not large enough to elicit significant increases in seagrass weight-specific productivity. This possibility is supported by the observation that the lowest mean value of epiphyte biomass, recorded for the grazed, ambient nutrient treatment in the spring trial, coincided with the highest mean value of seagrass weight-specific productivity, which was several-fold higher than any other mean value of seagrass weight-specific productivity in our study. However, other treatments with low values of epiphyte biomass, albeit not as low as the grazed, ambient nutrient treatment in the spring trial, did not result in comparatively enhanced values of seagrass weight-specific productivity.

Our results also set qualitative bounds to the potential bias committed when epiphyte grazing rates are estimated simply as the difference in the rates of epiphyte biomass accrual between non-grazed and grazed treatments. We did not measure nonconsumptive losses, but our calculations suggest that when the reduction in epiphyte absolute productivity by grazers found in our experiments is accounted for, estimates of epiphyte grazing rates may be 2 to $30 \%$ lower than estimates solely derived as the difference in the rates of epiphyte biomass accrual between non-grazed and grazed treatments. The extent of these differences would be larger if rates of non-consumptive losses are enhanced in the presence of grazers. However, our calculations are only approximations since they rely on a number of untested assumptions, i.e. (1) that rates of non-consumptive losses under non-grazed and grazed conditions cancel each other out, which seems to be a rather unrealistic assumption, (2) that daily rates of epiphyte biomass accrual are constant throughout the experiment, and (3) that the rates of epiphyte absolute productivity measured during the incubation period (from 09:00 to 12:00 h) are applicable to all daylight hours on the incubation day. At any rate, and despite the uncertainty of these untested assumptions, our calculations suggest that caution should be exerted when using epiphyte grazing estimates solely based on the difference in the rates of epiphyte biomass accrual between non-grazed and grazed conditions since such estimates may be considerably biased.

In conclusion, we show here that the effects of grazing and nutrient enrichment on diverse metrics of epiphyte growth can be disparate. Under the ambient eutrophic conditions of our experiments, further nutrient enrichment affected epiphyte biomass little in comparison with the effects of grazing. We found a significant increase of epiphyte biomass following nutrient enrichment only in 1 trial and under the presence of grazers, but decreases of epiphyte biomass due to grazing were more common throughout our experiments. In contrast, grazing and nutrients appeared to have an overall similar importance as controls of epiphyte productivity both expressed on a leaf or epiphyte weight unit basis. Thus, these 
results illustrate that studies aimed at examining the effects of environmental and biological controls on epiphyte growth dynamics and functional implications for the system should consider several epiphyte growth metrics since the effects on one given metric may be quite different from those on other metrics. Perhaps studies of grazing and nutrient effects on epiphyte dynamics should shift from the biomasscentric view mostly applied to date to a broader approach in which other metrics of epiphyte growth, such as productivity, are also considered. Indeed, such biomass-centric views, also have other risks since we show here that grazing rate estimates solely derived as the difference in biomass accrual rates between non-grazed and grazed rates can be considerably biased.

Acknowledgements. We thank Dr. J. Valentine and Dr. K. Heck Jr. for their insight in developing this paper and $\mathrm{K}$. Blankenhorn for her assistance with the field collection and lab processing. Three anonymous reviewers helped improve the paper substantially. We also express our gratitude to P. Dickey for the use of his property and dock as a field site for this and other projects. J.P.S. and B.C. were supported by graduate fellowships from the Department of Marine Sciences at the University of South Alabama and from the Mississippi-Alabama Sea Grant Consortium. This publication was supported by the National Sea Grant College Program of the US Department of Commerce's National Oceanic and Atmospheric Administration under grants NA86RG0039 and NA16RG2258, the Mississippi-Alabama Sea Grant Consortium and the Alabama Center for Estuarine Studies (grant \# 5-21838). The views expressed herein do not necessarily reflect the views of any of those organizations.

\section{LITERATURE CITED}

Agustí S, Enríquez S, Frost-Christensen H, Sand-Jensen K, Duarte CM (1994) Light harvesting in the plant kingdom. Funct Ecol 8:273-279

Anton A, Cebrian J, Duarte CM, Heck KL, Goff J (2009) Low impact of Hurricane Katrina on seagrass community structure and functioning in the Northern Gulf of Mexico. Bull Mar Sci 85:45-59

Antón A, Cebrian J, Heck KL, Duarte CM, Sheehan KL, Miller MEC, Foster CD (2011) Decoupled effects (positive to negative) of nutrient enrichment on ecosystem services. Ecol Appl 21:991-1009

Arthur CR, Rigler FH (1967) A possible source of error in the ${ }^{14} \mathrm{C}$ method of measuring primary productivity. Limnol Oceanogr 12:121-124

Baggett LP, Heck KL Jr, Frankovich TA, Armitage AR, Fourqurean JW (2010) Nutrient enrichment, grazer identity, and their effects on epiphytic algal assemblages: field experiments in subtropical turtlegrass Thalassia testudinum meadows. Mar Ecol Prog Ser 406:33-45

Borum J (1987) Dynamics of epiphyton on eelgrass (Zostera marina L.) leaves: relative roles of algal growth, herbivory and substratum turnover. Limnol Oceanogr 32: 986-992
Borum J, Sand Jensen K (1996) Is total primary production in shallow coastal marine waters stimulated by nitrogen loading? Oikos 76:406-410

> Bostrom C, Mattila J (1999) The relative importance of food and shelter for seagrass-associated invertebrates: a latitudinal comparison of habitat choice by isopod grazers. Oecologia 120:162-170

Capone DG, Penhale PA, Oremland RS, Taylor BF (1979) Relationship between productivity and $\mathrm{N}_{2}\left(\mathrm{C}_{2} \mathrm{H}_{2}\right)$ fixation in a Thalassia testudinum community. Limnol Oceanogr 24:117-125

Cebrian J (2004) Grazing on benthic primary producers. In: Nielsen SL, Banta GT, Pedersen MF (eds) Estuarine nutrient cycling: the influence of primary producers. Kluwer Academic Publishers, Dordrecht, p 153-185

Cebrian J, Enriquez S, Fortes M, Agawin N, Vermaat JE, Duarte CM (1999) Epiphyte accrual on Posidonia oceanica (L.) Delile leaves: implications for light absorption. Bot Mar 42:123-128

> Cebrian J, Drew Foster C, Plutchak R, Sheehan KL and others (2008) The impact of Hurricane Ivan on the primary productivity and metabolism of marsh tidal creeks in the North Central Gulf of Mexico. Aquat Ecol 42:391-404

Cebrian J, Corcoran AA, Stutes AL, Stutes JP, Pennock JR (2009) Effects of ultraviolet-B radiation and nutrient enrichment on the productivity of benthic microalgae in shallow coastal lagoons of the North Central Gulf of Mexico. J Exp Mar Biol Ecol 372:9-21

Cebrian J, Stutes AL, Phipps S, Stutes JP, Christiaen B, Pennock JR (2012) Effects of short-term sediment nutrient enrichment and grazer (Neritina reclivata) removal on sediment microalgae in a shallow eutrophic estuary (Alabama, USA). Int J Trop Biol 60:1687-1706

Dauby P, Poulicek M (1995) Methods for removing epiphytes from seagrasses: SEM observations on treated leaves. Aquat Bot 52:217-228

> Douglass JG, France KE, Richardson JP, Duffy JE (2010) Seasonal and interannual change in a Chesapeake Bay eelgrass community: insights into biotic and abiotic control of community structure. Limnol Oceanogr 55: 1499-1520

> Downing JA, Osenberg CW, Sarnelle O (1999) Metaanalysis of marine nutrient-enrichment experiments: variation in the magnitude of nutrient limitation. Ecology 80:1157-1167

Duarte CM (1995) Submerged aquatic vegetation in relation to different nutrient regimes. Ophelia 41:87-112

> Duffy JE, Hay ME (2000) Strong impacts of grazing amphipods on the organization of a benthic community. Ecol Monogr 70:237-263

> Duffy JE, Canuel EA, Richardson JP (2003) Grazer diversity and ecosystem functioning in seagrass beds. Ecol Lett 6: $637-645$

Enríquez S (2005) Light absorption efficiency and the package effect in the leaves of the seagrass Thalassia testudinum. Mar Ecol Prog Ser 289:141-150

Enríquez S, Duarte CM, Sand-Jensen K, Nielsen SL (1996) Broad scale comparison of photosynthetic rates across phototrophic organisms. Oecologia 108:197-206

- Gruner DS, Smith, JE, Seabloom EW, Sandlin SA and others (2008) A cross-system synthesis of consumer and nutrient resource control on producer biomass. Ecol Lett 11: $740-755$

- Hardison AK, Canuel EA, Anderson IC, Veuger B (2010) Fate of macroalgae in benthic systems: carbon and nitro- 
gen cycling with the microbial community. Mar Ecol Prog Ser 414:41-55

Hauxwell J, Valiela I (2004) Effects of nutrient loading on shallow seagrass- dominated coastal systems: patterns and processes. In: Nielsen SL, Banta GT, Pedersen MF (eds) Estuarine nutrient cycling: the influence of primary producers. Kluwer Academic Publishers, Dordrecht, p 59-92

Hauxwell J, Cebrian J, Furlong C, Valiela I (2001) Macroalgal canopies contribute to eelgrass (Zostera marina) decline in temperate estuarine ecosystems. Ecology 82: 1007-1022

> Hauxwell J, Cebrian J, Valiela I (2003) Eelgrass Zostera marina loss in temperate estuaries: relationship to landderived nitrogen loads and effect of light limitation imposed by algae. Mar Ecol Prog Ser 247:59-73

> Heck KL Jr, Pennock JR, Valentine JF, Coen LD, Sklenar SA (2000) Effects of nutrient enrichment and small predator density on seagrass ecosystems: an experimental assessment. Limnol Oceanogr 45:1041-1057

> Heck KL Jr, Hays G, Orth RJ (2003) Critical evaluation of the nursery role hypothesis for seagrass meadows. Mar Ecol Prog Ser 253:123-136

Heck KL Jr, Valentine JF, Pennock JR, Chaplin G, Spitzer PM (2006) Effects of nutrient enrichment and grazing on shoalgrass Halodule wrightii and its epiphytes: results of a field experiment. Mar Ecol Prog Ser 326:145-156

Hemminga MA, Duarte CM (2000) Seagrass ecology, Vol 2. Cambridge University Press, Cambridge

Hillebrand H, Kahlert M (2002) Effect of grazing and water column nutrient supply on biomass and nutrient content of sediment microalgae. Aquat Bot 72:143-159

> Hillebrand H, Worm B, Lotze HK (2000) Marine microbenthic community structure regulated by nitrogen loading and grazing pressure. Mar Ecol Prog Ser 204:27-38

> Hughes AR, Bando KJ, Rodriguez LF, Williams SL (2004) Relative effects of grazers and nutrients on seagrasses: a meta-analysis approach. Mar Ecol Prog Ser 282:87-99

Jaschinski S, Sommer U (2010) Positive effects of mesograzers on epiphytes in an eelgrass system. Mar Ecol Prog Ser 401:77-85

> Jernakoff P, Nielsen J (1997) The relative importance of amphipod and gastropod grazers in Posidonia sinuosa meadows. Aquat Bot 56:183-202

Jernakoff P, Brearley A, Nielsen J (1996) Factors affecting grazer-epiphyte interactions in temperate seagrass meadows. Oceanogr Mar Biol Annu Rev 34:109-162

> Kemp WM, Lewis MR, Jones TW (1986) Comparison of methods for measuring production of the submersed macrophyte, Potamogeton perfoliatus L. Limnol Oceanogr 31: 1322-1334

Klumpp DW, Salita-Espinosa JS, Fortes MD (1992) The role of epiphytic periphyton and macroinvertebrate grazers in the trophic flux of a tropical seagrass community. Aquat Bot 43:327-349

> Klumpp DW, Salita-Espinosa JS, Fortes MD (1993) Feeding ecology and the trophic role of sea urchins in a tropical seagrass community. Aquat Bot 45:205-229

> Legendre L, Demers S, Yentsch CM, Yentsch CS (1983) The ${ }^{14} \mathrm{C}$ method: patterns of dark $\mathrm{CO}_{2}$ fixation and DCMU correction to replace the dark bottle. Limnol Oceanogr 28:996-1003

> Luczkovich JJ, Norton SF, Gilmore RG Jr (1995) The influence of oral anatomy on prey selection during the ontogeny of two percoid fishes, Lagodon rhomboides and Centropomus undecimalis. Environ Biol Fishes 44: 79-95

Markager S (1998) Dark uptake of inorganic ${ }^{14} \mathrm{C}$ in oligotrophic waters. J Plankton Res 20:1813-1836

Mateo MA, Cebrian J, Dunton K, Mutchler T (2006) Carbon flux in seagrass ecosystems. In: Larkum AWD, Orth RJ, and Duarte CM (eds) Seagrasses: biology, ecology and conservation. Springer, New York, NY, p 159-192

Moncreiff CA, Sullivan MJ, Daehnick AE (1992) Primary production dynamics in seagrass beds of Mississippi Sound: the contributions of seagrass, epiphytic algae, sand microflora, and phytoplankton. Mar Ecol Prog Ser 87:161-171

Moore KA, Wetzel RL (2000) Seasonal variations in eelgrass (Zostera marina L.) responses to nutrient enrichment and reduced light availability in experimental ecosystems. J Exp Mar Biol Ecol 244:1-28

> Morgan MD, Kitting CL (1984) Productivity and utilization of the seagrass Halodule wrightii and its attached epiphytes. Limnol Oceanogr 29:1066-1076

Neckles HA, Wetzel RL, Orth RJ (1993) Relative effects of nutrient enrichment and grazing on epiphyte-macrophyte (Zostera marina L.) dynamics. Oecologia 93:285-295

Neckles HA, Koepfler ET, Haas LW, Wetzel RL, Orth RJ (1994) Dynamics of epiphytic photoautotrophs and heterotrophs in Zostera marina (eelgrass) microcosms: responses to nutrient enrichment and grazing. Estuaries 17:597-605

Orth RJ, Van Montfrans J (1984) Epiphyte-seagrass relationships with an emphasis on the role of micrograzing: a review. Aquat Bot 18:43-69

> Orth RJ, Carruthers TJB, Dennison WC, Duarte CM and others (2006) A global crisis for seagrass ecosystems. Bioscience 56:987-996

Pennock JR, Cowan JLW (2001) Analytical instrumentation methods manual. Tech Rep 98-003. Marine Environmental Sciences Consortium, Dauphin Island, AL

> Peterson B (1980) Aquatic primary productivity and the ${ }^{14} \mathrm{C}$ $\mathrm{CO}_{2}$ method: a history of the productivity problem. Annu Rev Ecol Syst 11:359-385

> Peterson BJ, Frankovich TA, Zieman JC (2007) Response of seagrass epiphyte loading to field manipulations of fertilization, gastropod grazing and leaf turnover rates. J Exp Mar Biol Ecol 349:61-72

> Pilon J, Santamaria L, Hootsmans M, van Vierssen W (2003) Latitudinal variation in life-cycle characteristics of Potamogeton pectinatus L.: vegetative growth and asexual reproduction. Plant Ecol 165:247-262

Plutchak R, Major K, Cebrian J, Foster CD and others (2010) Impacts of oyster reef restoration on primary productivity and nutrient dynamics in tidal creeks of the North Central Gulf of Mexico. Estuaries Coasts 33:1355-1364

Ralph PJ (1999) Photosynthetic response of Halophila ovalis (R-Br.) Hook. f. to combined environmental stress. Aquat Bot 65:3-96

Ralph PJ, Gademann R, Dennison WC (1998) In situ seagrass photosynthesis measured using a submersible, pulse-amplitude modulated fluorometer. Mar Biol 132: 367-373

> Rizzo WM, Lackey GJ, Christian RR (1992) Significance of euphotic, subtidal sediments to oxygen and nutrient cycling in a temperate estuary. Mar Ecol Prog Ser 86:51-61

Sand-Jensen K, Borum J (1984) Epiphyte shading and its effect on photosynthesis and diel metabolism of Lobelia dortmanna L. during the spring bloom in a Danish Lake. 
Aquat Bot 20:109-119

Sand-Jensen K, Borum J (1991) Interactions among phytoplankton, periphyton and macrophytes in temperate freshwaters and estuaries. Aquat Bot 41:137-175

Sfriso A, Marcomini A (1997) Macrophyte production in a shallow coastal lagoon. Part I: coupling with chemicophysical parameters and nutrient concentrations in waters. Mar Environ Res 44:351-375

Silberstein K, Chiffings AW, McComb AJ (1986) The loss of seagrass in Cockburn Sound, Western Australia. 3. The effect of epiphytes on productivity of Posidonia australis Hook. F. Aquat Bot 24:355-371

Spitzer PM, Heck KL Jr, Valentine JF (2003) Then and now: a comparison of patterns in blue crab post-larval abundance and post-settlement mortality during the early and late 1990s in the Mobile Bay system. Bull Mar Sci 72: 435-452

Steemann Nielsen E (1951) Measurement of the production of organic matter in the sea by means of carbon-14. Nature 167:684-685

Strickland JDH, Parsons TR (1972) A practical handbook of seawater analysis, 2nd edn. Bull Fish Res Board Can 167: $1-310$

Stutes J (2000) The relative importance of vertebrate and invertebrate grazing on seagrass epiphytes in the Northern Gulf of Mexico: an experimental assessment. MSc thesis, University of South Alabama, Mobile, AL

Stutes AL, Cebrian J, Corcoran AA (2006) Effects of nutrient enrichment and shading on sediment primary production and metabolism in eutrophic estuaries. Mar Ecol Prog

Editorial responsibility: Hans Heinrich Janssen,

Oldendorf/Luhe, Germany
Ser 312:29-43

Stutes J, Cebrian J, Stutes AL, Hunter A, Corcoran AA (2007) Benthic metabolism across a gradient of anthropogenic impact in three shallow coastal lagoons in NW Florida. Mar Ecol Prog Ser 348:55-70

Sundbäck K, Enoksson V, Granéli W, Pettersson K (1991) Influence of sublittoral microphytobenthos on the oxygen and nutrient flux between sediment and water: a laboratory continuous-flow study. Mar Ecol Prog Ser 74: 263-279

Tomas F, Turon X, Romero J (2005) Effects of herbivores on a Posidonia oceanica seagrass meadow: importance of epiphytes. Mar Ecol Prog Ser 287:115-125

> Van Montfrans J, Wetzel RL, Orth RJ (1984) Epiphyte-grazer relationships in seagrass meadows: consequences for seagrass growth and production. Estuaries 7:289-309

Virnstein RW, Mikkelsen PS, Cairns KD, Capone MA (1983) Seagrass beds versus sand bottoms: the trophic importance of their associated benthic invertebrates. Fla Sci 46:363-381

Wetzel RG (1964) A comparative study of the primary productivity of higher aquatic plants, periphyton and phytoplankton in a large, shallow lake. Int Rev Gesamten Hydrobiol 49:1-61

> Williams SL, Ruckelshaus MH (1993) Effects of nitrogen availability and herbivory on eelgrass (Zostera marina) and epiphytes. Ecology 74:904-918

> Worm B, Reusch TBH, Lotze HK (2000) In situ nutrient enrichment: methods for marine benthic ecology. Int Rev Hydrobiol 85:359-375

Submitted: October 27, 2011; Accepted: October 8, 2012 Proofs received from author(s): January 16, 2013 